\title{
Fizyolojik ve Morfolojik Parametreler Kullanarak Bazı İleri Soya (Glycine max. L.) Hatlarının Şanlıurfa İkinci Ürün Koşullarında Verim Özellikleri Yönünden Performanslarının Araştırııması
}

\author{
Erdal ERBíl ${ }^{1 *}$, M. Atilla GÜR ${ }^{2}$ \\ ${ }^{1}$ GAP Tarımsal Araştırma Enstitüsü Müdürlüğü, Şanlıurfa \\ [ORCID: http://orcid.org/0000-0001-6044-5165] \\ ${ }^{2}$ Harran Üniversitesi, Ziraat Fakültesi, Tarla Bitkileri Bölümü, Şanlıurfa \\ [ORCID: http://orcid.org/0000-0002-0176-9351] \\ "Sorumlu yazar: erdal.erbil@tarim.gov.tr
}

\begin{abstract}
Öz
Bu araştırma, bazı ileri soya hatlarıın, Şanlıurfa ikinci ürün koşullarında performanslarının, fizyolojik ve morfolojik parametreler kullanarak, belirlenmesi amacıyla yürütülmüştür. Çalışmada, melezleme yöntemiyle geliştirilmiş olan, 11 ileri hat (KA08-03, KA08-06, KA08-07, KA08-08, KA08-09, 8-3-4, 11, 13, $17,24,27$ ) ve 3 standart çeşit (Türksoy, Ataem-7, Bravo) materyal olarak kullanılmıştır. Araştırma, GAP Tarımsal Araştırma Enstitüsü Gündaş Araştırma İstasyonu'nda 2015, 2016 yıllarında yürütülmüştür. Araştırmada, fizyolojik olgunluk gün sayısı (FOGS), bin tohum ağırlığı (BTA), toprak bitki gelişim analizi (SPAD), tohum verimi (V), normalize edilmiş fark bitki örtüsü indeksi (NDVI) ve kanopi sıcaklığı (KS) özellikleri incelenmiştir. Araştırma sonuçlarına göre; iki yıllık veriler ayrı ayrı değerlendirildiğinde, bitkide kanopi sıcaklı̆ı̆ genotipler arasında istatistiksel fark 0.05 düzeyinde olup, incelenen diğer özellikler yönünden 0.01 önem derecesinde, fark oluşmuştur. İncelenen soya genotipleri arasında, tohum verimi 226.69-370.51 $\mathrm{kg} \mathrm{da}^{-1}$, fizyolojik olgunluk gün sayısı 104.63-120.63 gün, kanopi sıcaklığı $23.87-25.84{ }^{\circ} \mathrm{C}$, SPAD değeri 33.76-40.45 ve NDVI 0.641-0.761 arasında değişmiştir. Soya genotiplerinden elde edilen tohum verimi ile $\mathrm{R} 2$ (tam çiçeklenme) döneminde ölçümü yapılan SPAD ( $\left.r=0.40^{* *}\right)$ ve NDVI ( $\left.r=0.4261^{* *}\right)$ değerleri arasında, istatistiksel olarak pozitif ve önemli $(p<0.01)$ korelasyon olduğu, tespit edilmiştir. Tohum verimi ile kanopi sıcaklığının, R5 (tam tohum oluşumu) dönemindeki ölçümüyle ise istatistiksel olarak negatif $\left(r=-0.5399^{*}\right)$ ve önemli $(p<0.05)$ korelasyon olduğu görülmüştür.
\end{abstract}

Anahtar Kelimeler: Soya, Fizyoloji, Verim, SPAD, NDVI

\section{Investigation of Performance of Some Advanced Soybean Lines at Şanlıurfa Second Crop Conditions Using Physiological and Morphological Parameters Regarding Traits of Yield}

\begin{abstract}
In order to determine performance of some advanced soybean lines was carried out at Şanlıurfa main crop conditions. In this study, 11 advanced lines developed by hybridization methods (KA08-03, KA0806, KA08-07, KA08-08, KA08-09, 8-3-4, 11, 13, 17, 24, 27) and 3 standard cultivars (Türksoy, Ataem-7, Bravo) were used as materials. The research was carried out in the GAP Agricultural Research Institute Gündaş Research Station in second crop condition in 2015 and 2016. In the research, the number of physiological maturity days (FOGS), SPAD (S), NDVI (N) and canopy temprature were examined. According to research results; significant differences were identified $(p<0.01)$ statistically among soybean lines in terms of all features except for the physiological maturity days $(p<0.05)$ in years are examined separately. Grain yield of soybean genotypes studied 226.69-370.51 kg da ${ }^{-1}$ physiological maturity days $104.63-120.63$, canopy temprature $23.87-25.84{ }^{\circ} \mathrm{C}$, SPAD value $33.76-40.45$ and NDVI value $0.641-0.761$ between changed. It was determined that there was a statistically significant $(p<0.01)$
\end{abstract}


correlation between grain yields obtained from soybean genotypes and SPAD $(r=0.40 * *)$ and NDVI ( $r=$ $0.4261^{* *}$ ) values measured during R2 (full flowering) development period. It was observed that there was statistically negative $\left(r=-0.5399^{*}\right)$ and significant $(p<0.05)$ correlation with grain yield and canopy temperature measured at R5 (begening seed) period.

Key Words: Soybean, Physiology, Yield, SPAD, NDVI

\section{Giriş}

Baklagiller familyasından olan soya; dünyanın en önemli endüstri bitkilerindendir. Soya tohumu, içermiş olduğu \% 18-22 yağ ve \% 40-42 protein bakımından, insan beslenmesinde önemli bir yere sahiptir (Çopur ve ark., 2009). Soya, hem topraktan kaldırdığı azotu hem de, Bradyrhizobium japonicum bakterileri vasıtasıyla, atmosferden fikse ettiği azotu kullanabilme yeteneğine sahip bir bitkidir (Söğüt, 2005).

Soya, üretimi yapılan tek yıllık en önemli protein ve yağ bitkisidir. Dünyada 306.519.256 ton soya üretimi yapılmaktadır. Bu üretimin yaklaşık \% 35'i ABD'de, \% 29'u Brezilya'da, \% 18'i Arjantin'de ve \% 5 kadarı Çin'de gerçekleşirken, kalan \% 15'lik kısım ise Asya ve Amerika kıtasında yer alan ülkelerden elde edilmektedir (FAO, 2014). TÜik verilerine göre, 1997 yılında ülkemizde üretim 40.000 ton, dekara soya tohum verimi $211 \mathrm{~kg}$ iken, 2015 yılında üretim 165.000 tona, verim 432 kg da ${ }^{-1}$ a kadar yükselmiştir (Anonim, 2016a).

Soya bitkisinin büyüme ve gelişmesi çevre koşullarından çok fazla etkilenmekte, fotoperyoda tepkileri çeşitlere göre farklılık göstermektedir (Zhang ve ark., 2001). Fotoperyoda tepkilerine göre soya çeşitleri, ekvatorun kuzeyinden başlamak üzere, kutuplara doğru, 12 değişik yetişme grubu içerisinde sınıflandırılmaktadır. Genel olarak, kısa gün bitkisi olarak tanımlanan soya, uzun gün koşullarında daha fazla sayıda çiçek oluşturmakta, ancak, çiçek silkme oranı artmaktadır (Arıoğlu, 2000).

Soyada çeşit geliştirmek için, söz konusu edilen durum ve şartlara göre önceliklerin belirlenip bu doğrultuda çeşit ıslah çalışmalarının yapılması önem arz etmektedir. Islah çalışmalarıyla, verim ve tarımsal özellikler bakımından üstün olan, yeni çeşitlerin geliştirilmesi amaçlanmaktadır. Geliştirilen yeni hat veya çeşitlerin farklı ekolojik koşullarda, farklı sonuçlar verdiği bilinmektedir. Bu nedenle, bölgesel adaptasyon çalışmaları, özellikle yeni çeşit veya hatlar için önem arz etmektedir. Çeşit geliştirme programlarında başarının temel stratejilerden ilki, bölge koşullarında çalışılan bitkide, verim ve kaliteyi oluşturan özelliklerin, birbirleriyle ve fizyolojik olaylarla etkileşimlerinin ıslahçı tarafından iyi kavranmasıdır (PoehIman, 1979).

Soyada dünya çapında yapılan fizyolojik araştırmalar sonucunda, zararlılara karşı, yeni yaklaşımlar geliştirilmiştir. Böylece birim alandan elde edilen verimin arttırılmasına ve girdilerin azaltılmasıyla da, tohum kalitesinde artışlar elde edilmiştir. 
(Sinclair ve Vadez, 2012; Van Roekel ve Purcell, 2014). Soyanın, ekimden vejetatif döneminin sonuna kadar, fizyolojik olarak beslenmesi iyi takip edilmelidir. Özellikle bitki, gelişme döneminde, fizyolojik değişimlere karşı çok hassastır.

Bitkilerde fizyolojik değişimlerin takip edilmesinde kullanılan, NDVI (Normalized Difference Vegetation Index), bitki yüzeyinden yansıyan yakın kızılötesi (NIR) ve görünür kızılötesi (Red) dalga boyuna dayanan ve yaygın olarak kullanılan bir bitki örtüsü indeksidir (Plant ve ark., 2001; Gutierrez ve ark., 2012). Generatif dönemde ortaya çıkan önemli SPAD (Soil Plant Analysis Development) ve BÖS (Bitki Örtüsü Sıcaklığı) ilişkilerinin serinleme yeteneği yüksek ve yüksek klorofil içerikli bitki elde edilmesindeki genetik ilerlemeyi artıracağı belirtilmiştir (Babar ve ark., 2006). Son dönemlerde buğdayda SPAD (Hede ve ark., 1999; Rharrabti ve ark., 2001) ve BÖS (Reynolds ve ark., 1998; Royo ve ark., 2002) ölçümleri ile başarılı çalışmalar gerçekleştirilmiş olmasına rağmen, ülkemiz koşullarında SPAD ve BÖS'nın kullanılabilirliği, sınırlı sayıdaki çalışmalarla birlikte, henüz tam olarak açıklığa kavuşturulamamıştır (Yıldırım, 2005; Çekiç, 2007).

$\mathrm{Bu}$ çalışma; melezleme yoluyla elde edilmiş, ileri soya hatlarının, Şanlıurfa ikinci ürün koşullarında, performanslarını belirleyerek bölgeye uygun erkenci ve yüksek verimli çeşit adaylarını, erken jenerasyonlarda belirlerken, fizyolojik parametrelerin kullanılma olanaklarının araştırılması amacıyla yürütülmüştür.

\section{Materyal ve Yöntem}

$\mathrm{Bu}$ araştırmada; 11 ileri hat (KA08-03, KA08-06, KA08-07, KA08-08, KA08-09, 83-4, 11, 13, 17, 24, 27) 3 standart çeşit (Bravo, Türksoy, Ataem-7) materyal olarak kullanılmıştır. Hatlar, Karadeniz Tarımsal Araştırma Enstitüsü ve GAP Tarımsal Araştırma Enstitüsü tarafından yürütülen, soya ıslah çalışmalarında, ileri çıkan orta-erkenci gruba dâhil hatlardır. Çalışma, 2015 ve 2016 yıllarında GAP Tarımsal Araştırma Enstitüsü Müdürlüğünün Gündaş Araştırma İstasyonu'nda yürütülmüştür. Gündaş Araştırma İstasyonu, toprak ana materyali, killi kireçli toprak tipinde olup, killi-tınlı yapıya sahiptir. Düze yakın eğimli topraklar, derin bir yapılı ve alkali (pH 7.9) yapıya sahiptir. Organik maddece fakir (1.2) olan topraklar aşağıya doğru tüm profilleri potasyumca zengindir (Erbil, 2013).

Denemenin yürütüldüğü istasyonun, Haziran-Ekim aylarını kapsayan vejetasyon döneminde ortalama hava sıcaklığı, 2015 yılına $26.53{ }^{\circ} \mathrm{C}, 10 \mathrm{~cm}$ toprak altı ortalama sıcaklığı $28.7{ }^{\circ} \mathrm{C}$ ölçülürken, 2016 yılında ise, sırasıyla $27.01{ }^{\circ} \mathrm{C}, \quad 30.2{ }^{\circ} \mathrm{C}$ olmuştur. Deneme yıllarında vejetasyon süresi boyunca, ortalama bağıl nem miktarları ise yıl sırasıyla, \%43.6 ile \%43.3 olarak gerçekleşmiştir. Şanlıurfa ilinde ikinci ürün soya vejetasyon döneminin her iki yılında da, yağış gerçekleşmemiştir (Anonim, 2016b). 
Çizelge 1. Deneme alanına ait bazı toprak özellikleri (Anonim, 2015)

Table 1. Some soil properties of the experiment area (Anonimous, 2015)

\begin{tabular}{|c|c|c|c|c|c|c|c|}
\hline $\begin{array}{l}\quad \text { Toprak } \\
\text { derinliği }(\mathrm{cm}) \\
\text { Soil depth }\end{array}$ & $\begin{array}{c}\text { Ec }\left(\mathrm{ds} \mathrm{m}^{-1}\right) \\
\text { Salinity }\end{array}$ & $\begin{array}{c}\text { Kireç (\%) } \\
\text { Lime }\end{array}$ & $\mathrm{pH}$ & $\begin{array}{c}\text { Fosfor } \\
\text { Phosphorus } \\
\left(\mathrm{kg} \mathrm{da}^{-1}\right)\end{array}$ & $\begin{array}{l}\text { Potasyum } \\
\text { Potassium } \\
\left(\mathrm{kg} \mathrm{da}^{-1}\right)\end{array}$ & $\begin{array}{c}\text { Organik Mad. } \\
(\%) \\
\text { Organic } \\
\text { matter }\end{array}$ & $\begin{array}{c}\text { Suya } \\
\text { doy } \\
(\%) \\
\text { Saturation }\end{array}$ \\
\hline $0-30$ & 0.71 & 18,6 & 7,9 & 5,43 & 273,6 & 1,13 & 57 \\
\hline $30-60$ & 0.69 & 17,9 & 7,8 & 5,45 & 270,2 & 1,12 & 59 \\
\hline \multirow{2}{*}{$\begin{array}{c}\text { Tekstür } \\
\text { (Killi-Kumlu) } \\
\text { Structure } \\
\text { (Clay-Sandy) }\end{array}$} & Kum (\%) & $\mathrm{Kil}(\%)$ & Silt (\%) & & & & \\
\hline & 37 & 40 & 23 & & & & \\
\hline
\end{tabular}

Çizelge 2. Denemenin yürütüldüğü Akçakale ilçesine bağlı Gündaş Araştırma İstasyonu'na ilişkin 20152016 yılları ve uzun yıllar ortalama iklim değerleri (Anonim, 2016b)

Table 2. 2015-2016 Year and long-term Gündaş Akçakale District depends on the Experiment Station average execution research on climate values (Anonimous, 2016b)

\begin{tabular}{|c|c|c|c|c|c|c|}
\hline $\begin{array}{c}\text { Aylar } \\
\text { Mounts }\end{array}$ & $\begin{array}{l}\text { Yillar } \\
\text { Years }\end{array}$ & $\begin{array}{l}\text { Ortalama } \\
\text { Sicaklık } \\
\left({ }^{\circ} \mathrm{C}\right) \\
\text { Avarage air } \\
\text { temp. }\left({ }^{\circ} \mathrm{C}\right)\end{array}$ & $\begin{array}{l}\text { En yüksek } \\
\text { sıcaklık } \\
\left({ }^{\circ} \mathrm{C}\right) \\
\text { Max.air } \\
\text { temp. }\left({ }^{\circ} \mathrm{C}\right)\end{array}$ & $\begin{array}{l}\text { En düşük } \\
\text { sicaklık } \\
\left({ }^{\circ} \mathrm{C}\right) \\
\text { Min.air } \\
\text { temp. }\left({ }^{\circ} \mathrm{C}\right)\end{array}$ & $\begin{array}{c}\text { Ortalama } \\
\text { nispi nem } \\
(\%) \\
\text { Avarage } \\
\text { relative } \\
\text { humidity } \\
(\%)\end{array}$ & $\begin{array}{c}\text { Yağış } \\
(\mathrm{mm}) \\
\\
\text { Precipitation } \\
(\mathrm{mm})\end{array}$ \\
\hline \multirow{3}{*}{$\begin{array}{c}\text { Haziran } \\
\text { June }\end{array}$} & 2015 & 27.8 & 38.4 & 16.7 & 29.6 & 1.8 \\
\hline & 2016 & 29.8 & 42.0 & 18.9 & 39.2 & 0.2 \\
\hline & Uz.Yıl Ort.* & 28.4 & 36.1 & 18.3 & 38.8 & 1.3 \\
\hline \multirow{3}{*}{$\begin{array}{l}\text { Temmuz } \\
\text { July }\end{array}$} & 2015 & 33.2 & 42.8 & 21.4 & 33.6 & - \\
\hline & 2016 & 32.9 & 43.0 & 20.9 & 32.7 & - \\
\hline & Uz.Yıl Ort. & 31.5 & 39.8 & 21.4 & 38.8 & 0.6 \\
\hline \multirow{3}{*}{$\begin{array}{l}\text { Ağustos } \\
\text { August }\end{array}$} & 2015 & 31.5 & 43.1 & 22.1 & 35.5 & 1.2 \\
\hline & 2016 & 33.4 & 43.0 & 21.2 & 40.9 & 1.1 \\
\hline & Uz.Yıl Ort. & 30.5 & 39.2 & 20.7 & 42.0 & 0.1 \\
\hline \multirow{3}{*}{$\begin{array}{c}\text { Eylül } \\
\text { September }\end{array}$} & 2015 & 29.8 & 40.4 & 18.7 & 45.1 & 0.2 \\
\hline & 2016 & 26.5 & 39.3 & 14.7 & 39.6 & 1.3 \\
\hline & Uz.Yıl Ort. & 25.8 & 34.9 & 16.4 & 44.7 & 1.2 \\
\hline \multirow{3}{*}{$\begin{array}{c}\text { Ekim } \\
\text { October }\end{array}$} & 2015 & 21.7 & 33.0 & 12.7 & 56.6 & 13.6 \\
\hline & 2016 & 21.1 & 30.4 & 12.9 & 54.9 & 3.4 \\
\hline & Uz.Yıl Ort. & 19.4 & 26.9 & 14.6 & 51.8 & 19.3 \\
\hline \multirow{3}{*}{$\begin{array}{c}\text { Kasım } \\
\text { November }\end{array}$} & 2015 & 14.0 & 24.3 & 6.8 & 60.1 & 18.2 \\
\hline & 2016 & 12,3 & 20.1 & 5.6 & - & 19.6 \\
\hline & Uz.Yıl Ort. & 12.0 & 18.5 & 6.7 & 64.1 & 28.1 \\
\hline \multirow{3}{*}{$\begin{array}{c}\text { Aralık } \\
\text { December }\end{array}$} & 2015 & 8.7 & 20.0 & 0.5 & 82.1 & 16.4 \\
\hline & 2016 & 8.0 & 14.6 & 1.3 & - & 26.9 \\
\hline & Uz.Yıl Ort. & 7.5 & 12.1 & 2.3 & 73.7 & 44.5 \\
\hline
\end{tabular}

Tarla denemeleri, Tesadüf Blokları Deneme Desenine göre, 4 tekerrürlü olarak kurulmuştur. Her iki yılda da ekimler, Haziran ayı ortalarında
(14.06.2015 ve 16.06.2016) tavlı toprağa yapılmış; çıkıştan sonra yağmurlama, daha sonra ortalama 8 defa sulama yapılmıştır. Denemede yapılan toprak 
analizi dikkate alınarak, dekara $9 \mathrm{~kg}$ saf $\mathrm{N}$ 'un yarısı Amonyum Sülfat (AS) ekimle kalan diğer yarısı ise çiçeklenme döneminde, yine saf olarak $6 \mathrm{~kg} \mathrm{da}^{-1} \mathrm{P}_{2} \mathrm{O}_{5}$ TSP formunda, tabana ekimle birlikte uygulanmıştır. Her parsel, 4 sıradan oluşmuş ve sıra arası mesafesi $70 \mathrm{~cm}$, sıra üzeri mesafesi ise $4 \mathrm{~cm}$ olacak şekilde, deneme mibzeri ile ekimler yapılmıştır. Her bir hattın yer aldığı parsel alanı, 2.8 $\mathrm{m} \times 5 \mathrm{~m}=14 \mathrm{~m}^{2}$ olup, hasat sırasında kenar tesirlerinin çıkartılması ile 4.2 $\mathrm{m}^{2}$ ye düşürülmüştür. Deneme yıllarında, yetiştirme sezonu boyunca 2 defa traktör çapası yapılmıştır. İki deneme yılında da, hasat işlemleri Ekim ayı içerisinde (17.10.2015 ve 21.10.2016), her parselden orta iki sıra ve parsel başlarından birer metre kenar tesiri olarak bırakılarak gerçekleştirilmiştir. Araştırmada verim (V), fizyolojik olgunluk gün sayısı (FOGS), SPAD (S), NDVI (N) ve kanopi sıcaklığı (KS) gibi özellikler incelenmiştir. Bitkiler çıkışından bakla ve yaprakların \%95'inin kuruduğunun gözlendiği devreye kadarki gün sayısı, fizyolojik olgunluk gün sayısı olarak belirlenmiştir. SPAD, NDVI ve kanopi sıcaklık ölçümleri, soyada V3 (üç gerçek yapraklı dönem), R2 (tam çiçeklenme) ve R5 (tohum oluşum başlangıcı) gelişme dönemlerinde yapılmış her parselden, her dönemde 5 ölçüm yapılmış ve ortalaması alınmıştır. Ölçümler, günün saat 11:00-13:00 saatleri arasında bulutsuz havada yapılmıştır.

Elde edilen veriler, tesadüf blokları deneme desenine göre MSTAT-C paket program kullanılarak, varyans analizine tabi tutulmuştur. Önemlilik testlerinde
\%1 ve $\% 5$, farklı grupların belirlenmesinde her iki düzeyde kullanılmıştır. İstatistiki farklı gruplar AÖF (LSD) testi ile belirlenmiştir.

\section{Araştırma Bulguları ve Tartışma}

Çalışmada, fizyolojik olgunluk gün sayısı (gün), bin tohum ağırlığı (g) ve tohum verimine $\left(\mathrm{kg} \mathrm{da}{ }^{-1}\right)$ ait, yıllar birleştirilmiş ortalama değerler ve LSD testine göre oluşan gruplar Çizelge 3'te, SPAD, NDVI ve kanopi sıcaklığı $\left({ }^{\circ} \mathrm{C}\right)$ 'na ait değerler ise, Çizelge 4'te verilmiştir.

Çizelge 3'ten, fizyolojik olgunluk gün sayılarının 2015 yılında, 105 gün ile 122.33 gün arasında değiştiğini, ortalama 114.04 gün olduğu, 2016 yılında ise 103.42 gün ile 120.17 gün arasında değiştiğini ve ortalamanın 111.48 gün olduğu izlenebilmektedir. Aynı çizelgeden 2015 yılında en erken olgunlaşan çeşidin Ataem-7 çeşidi, 2016 yılında Bravo çeşidi olduğu, en geç hasat olgunluğuna erişen ise, sırasıyla KA08-07, KA08-08, KA08-06 hatları olduğu görülmektedir. LSD testine göre; her iki yılda da, fizyolojik olgunluk gün sayıları bakımından genotipler arasında istatistiksel anlamda önemli $(p<0.01)$ farklar bulunmuş farklı olgunlaşma grupları oluşmuştur. Bu durum hatların farklı olgunlaşma gruptaki ebeveynlerden melezlenmesinden ve farklı iklim ve toprak koşullarından, etkilenmiş olduklarından kaynaklanmış olabilir. Elde edilen bulgular, Yılmaz ve ark. (2005), Güneş (2006), Çetin (2010), Dolapçı (2012)'nın bulgularıyla, tam olarak uyum içinde olup, Ünal (2007), Erdoğmuş (2007), Arslan (2007) ve Malik 
ve ark. (2011) 'nın bulgularıyla da kısmen uyumludur. Çizelge 3 'ten denemeye konu olan genotiplerin, bin tohum ağırlığının, 2015 yılında, 142.45 g ile $183.68 \mathrm{~g}$ arasında değiştiği; ortalamanın 155.89 g olduğu, 2016 yılında ise 142.65 g ile 184.93 g arasında değiştiği ve ortalamanın $155.53 \mathrm{~g}$ olduğu izlenebilmektedir. Aynı çizelgeden, her iki yılda da en düşük bin tohum ağırlığına sahip hattın, KA08-09 hattı olduğu ve en yüksek bin tohum ağırlığına sahip hattın ise KA08-07 hattın olduğu görülmektedir. Yapılan varyans analizine göre her iki yılda da, genotipler arasında önemli $(p<0.01)$ farklar olduğu ve LSD testine göre grupların oluştuğu, tespit edilmiştir. Soya bitkisinde bin tohum ağırlığı, genotip, çevre koşulları, ekim zamanı, kültürel bakım işlemleri gibi değişik faktörlerden etkilenen ve verimi belirleyen en önemli ölçütlerden biridir.

Çizelge 3. Araştırmada İncelenen Soya Hat ve Çeşitlerinde Fizyolojik Olgunluk Gün Sayısı, Bin Tohum Ağırlığı ve Dekara Tohum Verimine İlişkin Ortalama Değerler ve LSD Testine Göre Oluşan Gruplar

Table 3. The Mean Values of Physiological Maturity Days, Thousand Seed Weight and Seed Yield and Groups According to LSD Test in Soybean Lines and Cultivars Examined in the Study

\begin{tabular}{|c|c|c|c|c|c|c|}
\hline \multirow{3}{*}{$\begin{array}{l}\text { Genotipler } \\
\text { Genotypes }\end{array}$} & \multirow{2}{*}{\multicolumn{2}{|c|}{$\begin{array}{l}\text { Fizyolojik Olgunluk Gün Sayısı (gün) } \\
\text { Physiological Maturity Days (days) }\end{array}$}} & \multirow{2}{*}{\multicolumn{2}{|c|}{$\begin{array}{l}\text { Bin Tohum Ağırlığı (g) } \\
\text { Thousand Seed Weight (g) }\end{array}$}} & \multirow{2}{*}{\multicolumn{2}{|c|}{$\begin{array}{l}\text { Tohum Verimi }\left(\mathrm{kg} \mathrm{da}^{-1}\right) \\
\text { Seed Yeilds }\left(\mathrm{kg} \mathrm{da}^{-1}\right)\end{array}$}} \\
\hline & & & & & & \\
\hline & $2015^{* *}$ & $2016^{* *}$ & $2015^{* *}$ & $2016^{* *}$ & $2015^{* *}$ & $2016^{* *}$ \\
\hline $8-3-4$ & $114.33 \mathrm{c}$ & 109.58 ef & 147.24 efg & $145.74 \mathrm{fg}$ & $253.52 \mathrm{f}$ & $250.71 \mathrm{~g}$ \\
\hline Ataem-7 & $105.00 \mathrm{~g}$ & $104.25 \mathrm{~g}$ & $152.71 \mathrm{def}$ & $151.96 \mathrm{def}$ & $335.62 b$ & $342.05 \mathrm{bc}$ \\
\hline KA08-03 & $118.33 \mathrm{~b}$ & $111.67 \mathrm{cde}$ & $155.88 \mathrm{cde}$ & $156.13 \mathrm{cde}$ & $251.59 f$ & $243.53 \mathrm{fg}$ \\
\hline KA08-06 & $121.00 \mathrm{a}$ & $117.75 a b$ & $173.25 b$ & $173.51 b$ & $369.86 \mathrm{a}$ & $371.16 \mathrm{a}$ \\
\hline KA08-07 & $122.33 \mathrm{a}$ & $118.92 \mathrm{a}$ & $183.68 \mathrm{a}$ & $184.93 \mathrm{a}$ & $333.33 \mathrm{bc}$ & 341.27 bc \\
\hline KA08-08 & $118.67 \mathrm{~b}$ & $120.17 a$ & $162.79 \mathrm{c}$ & $162.54 \mathrm{c}$ & $330.59 \mathrm{bc}$ & 321.53 cde \\
\hline KA08-09 & $113.67 \mathrm{~cd}$ & 114.42 bc & $142.45 \mathrm{~g}$ & $142.65 \mathrm{~g}$ & 311.87 cde & 301.31 def \\
\hline 17 & 112.33 de & $106.75 \mathrm{fg}$ & $150.69 \mathrm{~d}-\mathrm{g}$ & $149.94 \mathrm{~d}-\mathrm{g}$ & $227.85 \mathrm{~g}$ & $225.54 \mathrm{~h}$ \\
\hline Türksoy & $112.00 \mathrm{def}$ & $105.42 \mathrm{~g}$ & $151.51 \mathrm{def}$ & $151.11 \mathrm{~d}-\mathrm{g}$ & 319.118 b-e & 313.36 def \\
\hline 11 & $112.33 \mathrm{de}$ & $113.67 \mathrm{~cd}$ & $158.02 \mathrm{~cd}$ & $157.27 \mathrm{~cd}$ & $371.23 \mathrm{a}$ & $360.81 a b$ \\
\hline 24 & 110.67 ef & 112.42 cde & $152.61 \mathrm{def}$ & $151.61 \mathrm{def}$ & 302.74 de & 298.67 ef \\
\hline 13 & $113.33 \mathrm{~cd}$ & 111.75 cde & 148.69 efg & $147.44 \mathrm{efg}$ & $297.72 \mathrm{e}$ & $291.91 \mathrm{f}$ \\
\hline 27 & $112.33 \mathrm{de}$ & 110.08 def & $158.86 \mathrm{~cd}$ & $158.23 \mathrm{~cd}$ & $322.83 \mathrm{bcd}$ & $322.26 \mathrm{~cd}$ \\
\hline Bravo & $110.33 \mathrm{f}$ & $103.42 \mathrm{~g}$ & $144.16 \mathrm{fg}$ & $144.41 \mathrm{fg}$ & $323.29 \mathrm{bcd}$ & 316.22 de \\
\hline $\begin{array}{l}\text { Ortalama } \\
\text { Means }\end{array}$ & 114.04 & 111.48 & 155.89 & 155.53 & 310.80 & 307.16 \\
\hline LSD & 1.80 & 3.89 & 8.85 & 9.06 & 22.07 & 23.80 \\
\hline Cv (\%) & 1.10 & 2.44 & 3.97 & 4.07 & 4.96 & 5.30 \\
\hline
\end{tabular}

Soyada tohum iriliğinin genotiplere göre, önemli derecede değişiklik gösterebilen bir özellik olduğu bildirilmiştir (Arıoğlu ve ark. 1992). Güneş (2006), Harran Ovası koşullarında bin tohum ağırlığının 140.10-153.85 g, değerleri arasında olduğunu Khan ve ark. (2011) Pakistan'da yaptıkları çalışmada 100 tohum ağırlığının 4.127-17.16 g arasında değiş̧iğini, Karakuş ve ark., (2011) Harran Ovası koşullarında bizim araştırmamızda kullandığımız hat ve 
çeşitlerinde içinde bulunduğu ikinci ürün soya araştırmalarında bin tohum ağırlığının 150.53-193.56 g arasında olduğunu bildirmişlerdir. Beyyavaş ve ark. (2007) 'de Şanlıurfa Harran Ovası Tarımsal Araştırma Enstitüsü, deneme alanında yaptıkları iki yıllık, ikinci ürün soya ekim zamanı denemesinde bin tohum ağırlığının ilk yıl 129.67-170.00 g arasında ikinci yıl ise 144.67-178.33 g arasında değiştiğini bildirdikleri çalışma ile bulgularımız arasında, kısmi uyum olduğu görülmüştür.

Çizelge 3'ten soyada tohum veriminin (kg da $\left.{ }^{-1}\right) 2015$ yılında $227.85 \mathrm{~kg} \mathrm{da}^{-1}$ ile $371.23 \mathrm{~kg} \mathrm{da}^{-1}$ arasında değiştiğini ve ortalama tohum veriminin $310.80 \mathrm{~kg} \mathrm{da}^{-1}$, 2016 yılında ise tohum veriminin 225.54 $\mathrm{kg} \mathrm{da}{ }^{-1}$ ile $371.16 \mathrm{~kg} \mathrm{da}^{-1}$ arasında değiştiği ve ortalamanın $307.16 \mathrm{~kg} \mathrm{da}^{-1}$ olduğu izlenebilmektedir. Tohum verimi bakımından hat ve çeşitler arasında önemli $(p<0.01)$ farklılıklar bulunduğu görülmektedir. Sarımehmetoğlu (2006), Adana ekolojik koşullarında, farklı lokasyonlarda, yaptığı çalışmada tohum veriminin, A3935 çeşidinde, 260-430 kg $\mathrm{da}^{-1}$, S4240 çeşidinde, $260-430 \mathrm{~kg} \mathrm{da}^{-1}$ ve Nova çeşidinde ise $230-480 \mathrm{~kg} \mathrm{da}{ }^{-1}$ arasında değiştiğini, Güneş (2006) Harran Ovası ikinci ürün koşullarında tane veriminin, 274.75-350.74 $\mathrm{kg} \mathrm{da}^{-1}$ arasında değiştiğini, Kınacı (2011) Çanakkale koşullarında, $134.2-405.9 \mathrm{~kg} \mathrm{da}{ }^{-1}$ arasında değiştiğini, Acar (2014) Kahramanmaraş ikinci ürün koşullarında, 192-319 kg da-1 arasında değiştiğini, Dolapçı (2012) Kahramanmaraş'ta yaptığı çalışmada, soyada tohum veriminin, 260.87-376.96 kg da ${ }^{-1}$ arasında değiştiğini bildirmiştir. Karakuş ve ark., (2011) Harran Ovası koşullarında bizim araştırmamızda kullandığımız hatlarında içinde bulunduğu ikinci ürün soya denemelerinde tohum veriminin 237.78$395.14 \mathrm{~kg} \mathrm{da}{ }^{-1}$ arasında olduğunu bildirmiş en yüksek verimin 11 nolu hattan alındığını tespit etmişlerdir.

Yapılan çalışmanın sonuçları, diğer araştırmacıların sonuçlarıyla, kısmen Karakuş ve ark., (2011)'nın sonuçlarıyla, tamamen uyum içerisinde olduğu görülmektedir Çizelge 4'ten genotiplerin, SPAD ölçüm değerlerinin, 2015 yılında 34.11 ile 39.97 değerleri arasında, 2016 yılında ise 33.42 ile 41.14 değerleri arasında olduğu izlenebilmektedir. Birçok araştırmacı, klorofilmetre (SPAD) ölçümleri ile bitkilerde yaprak azot içeriği arasında, pozitif ve önemli korelasyon olduğunu rapor etmişlerdir (Reeves ve ark., 1993 ve Matsunaka ve ark., 1997). NDVı ile verim tahmin çalışmaları, 1980'li yıllarda başlamış ve günümüz de yeni yaklaşımlarla geliştirilmeye çalışılmaktadır. NDVI ile yapılan çalışmaların çoğu tohum verimi ve NDVI ölçümleri arasındaki güçlü ilişkiyi göstermektedir. Buğday da (Manjunath ve ark., 2002), mısırda ve soyada (Prasad ve ark., 2006) ve çeltikte (Wang ve Huang, 2006), sorgum ve arpada (Kastens ve ark., 2005) yoncada (Ferencz ve ark., 2004) ve kolzada (Mkhbela ve ark., 2011) yapılan çalışmalarda verim tahmininde NDVI ölçümlerinin kullanılabileceğini göstermişlerdir. Ancak burada en iyi karar verilmesi gereken unsur bitkinin hangi gelişme döneminde NDVI ölçümlerinin alınması gerektiğidir. Şekil 
2'de görüleceği üzere, iki yıl birleşik arasındaki korelasyon grafiğinde $\mathrm{R} 2$ ( $\mathrm{r}=$ olarak V3, R2 ve R5 dönemlerinde alınmış $\left.0.4261^{* *}\right)$ ve R5 ( $\left.r=0.4960 * *\right)$ olan NDVI okumaları ile tohum verimi döneminde önemli ve pozitif ilişki vardır.

Çizelge 4. Araştırmada incelenen soya hat ve çeşitlerinde SPAD (toprak bitki gelişim analizi), NDVI (normalize edilmiş fark bitki örtüsü indeksi) ve kanopi sıcaklığına ait ortalama değerler ve LSD testine göre oluşan gruplar

Table 4. The Mean values of SPAD (soil plant analysis development), NDVI (normalized difference vegetation index) and canopy temperature and groups according to LSD test in soybean lines and cultivars examined in the study

\begin{tabular}{|c|c|c|c|c|c|c|}
\hline \multirow{3}{*}{$\begin{array}{l}\text { Genotipler } \\
\text { Genotypes }\end{array}$} & \multirow{2}{*}{\multicolumn{2}{|c|}{$\begin{array}{l}\text { SPAD } \\
\text { SPAD }\end{array}$}} & \multirow{2}{*}{\multicolumn{2}{|c|}{$\begin{array}{l}\text { NDVI } \\
\text { NDVI }\end{array}$}} & \multirow{2}{*}{\multicolumn{2}{|c|}{$\begin{array}{l}\text { Kanopi sıcaklığı }\left({ }^{\circ} \mathrm{C}\right) \\
\text { Canopy temperature }\left({ }^{\circ} \mathrm{C}\right)\end{array}$}} \\
\hline & & & & & & \\
\hline & $2015^{* *}$ & $2016^{* *}$ & $2015^{* *}$ & $2016^{* *}$ & $2015^{* *}$ & 2016 \\
\hline $8-3-4$ & $36.54 \mathrm{c}$ & 36.61 de & $0.565 \mathrm{e}$ & $0.716 \mathrm{f}$ & $25.57 \mathrm{abc}$ & 26.05 \\
\hline Ataem-7 & $36.64 \mathrm{bc}$ & 37.01 cde & 0.662 bc & $0.798 a b$ & $25.98 \mathrm{ab}$ & 25.69 \\
\hline KA08-03 & 39.97 a & $38.94 \mathrm{abc}$ & $0.644 \mathrm{~cd}$ & 0.778 bcde & $24.64 \mathrm{bcd}$ & 25.30 \\
\hline KA08-06 & 39.42 a & $39.65 a b$ & $0.699 a b$ & $0.822 a$ & $25.02 \mathrm{abcd}$ & 25.61 \\
\hline KA08-07 & 38.99 a & $39.36 \mathrm{ab}$ & $0.669 \mathrm{abc}$ & $0.811 \mathrm{a}$ & $24.45 \mathrm{bcd}$ & 25.07 \\
\hline KA08-08 & $38.21 \mathrm{abc}$ & 37.99 bcde & $0.675 a b c$ & $0.805 a b$ & $25.19 a b c$ & 25.18 \\
\hline KA08-09 & 36.79 bc & 37.53 bcde & $0.642 \mathrm{~cd}$ & $0.795 a b c$ & $24.11 \mathrm{~cd}$ & 24.44 \\
\hline 17 & $36.47 \mathrm{~cd}$ & $36.08 \mathrm{e}$ & $0.611 \mathrm{de}$ & $0.759 \mathrm{e}$ & $23.51 d$ & 24.51 \\
\hline Türksoy & $38.27 a b c$ & $38.41 \mathrm{bcd}$ & $0.611 \mathrm{de}$ & $0.761 \mathrm{de}$ & $26.54 \mathrm{a}$ & 24.54 \\
\hline 11 & $38.14 a b c$ & 37.89 bcde & $0.657 \mathrm{bc}$ & $0.792 \mathrm{abcd}$ & $23.49 d$ & 24.51 \\
\hline 24 & $38.17 a b c$ & 38.14 bcde & $0.660 \mathrm{bc}$ & $0.763 \mathrm{de}$ & $25.53 a b c$ & 26.07 \\
\hline 13 & $34.11 d$ & $33.42 \mathrm{f}$ & $0.662 b c$ & $0.755 \mathrm{e}$ & $24.64 \mathrm{bcd}$ & 25.12 \\
\hline 27 & $37.77 \mathrm{abc}$ & 37.91 bcde & $0.650 \mathrm{~cd}$ & 0.765 cde & $23.47 d$ & 24.28 \\
\hline Bravo & 39.76 a & $41.14 \mathrm{a}$ & $0.712 \mathrm{a}$ & $0.792 \mathrm{abcd}$ & $26.41 \mathrm{a}$ & 25.94 \\
\hline $\begin{array}{l}\text { Ortalama } \\
\text { Means }\end{array}$ & 37.81 & 37.86 & 0.651 & 0.779 & 24.89 & 25.16 \\
\hline LSD & 2.39 & 2.20 & 0.04 & 0.03 & 1.67 & Ö.D \\
\hline Cv (\%) & 4.42 & 4.06 & 5.26 & 2.83 & 4.71 & 7.16 \\
\hline
\end{tabular}




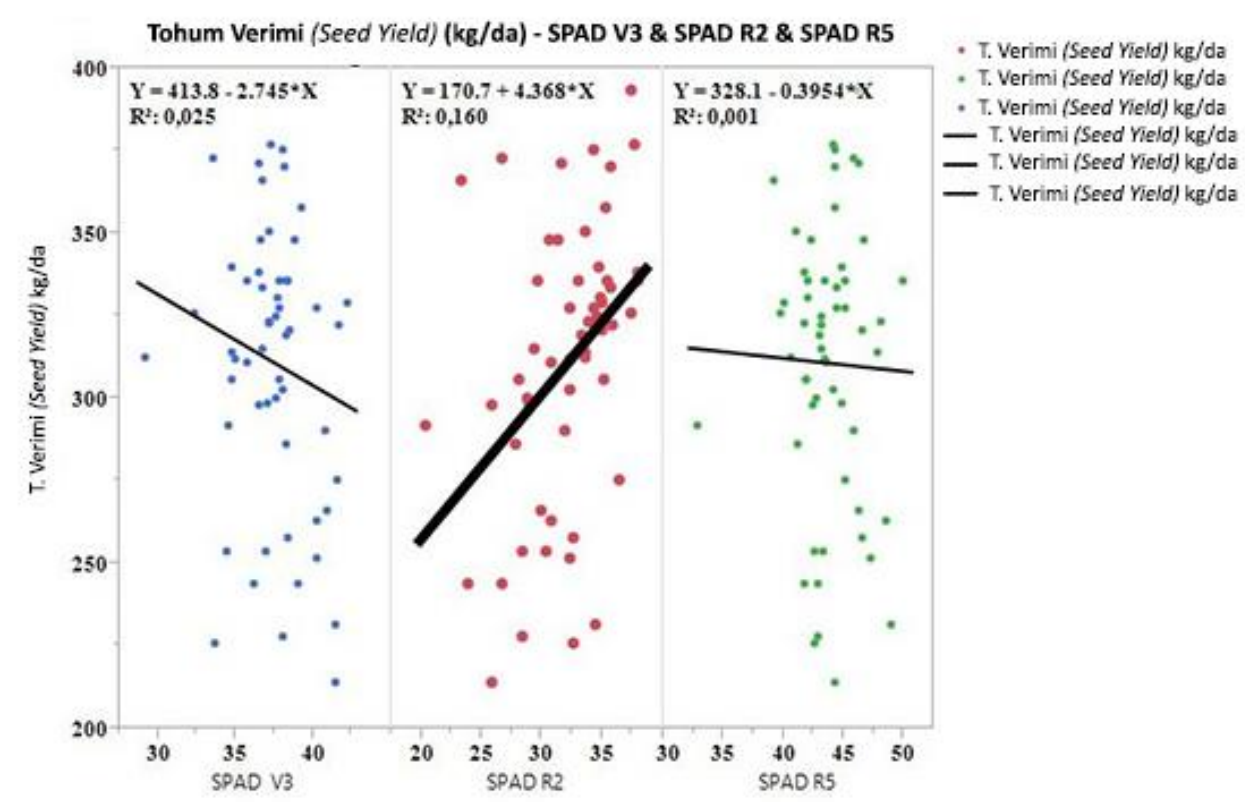

Şekil 1. Soya hat ve çeşitlerin 2015 yılı tohum verimi ve V3 (üç gerçek yapraklı dönem), R2 (tam çiçeklenme) ve R5 (tohum oluşum başlangıcı) büyüme dönemleri SPAD (toprak bitki gelişim analizi) değerleri arasındaki korelasyon grafiği

Figure 1. Correlation graph of values of seeds yield and V3 (three real leaf period), $R 2$ (full flowering) and R5 (beginning of seed creation) growth periods of soybean lines and varieties in 2015 SPAD (soil plant analysis development) values

Elde edilen bulgular ışığında, soyada tohum veriminin hasattan önce tahmin edilmesi yönünde yapılacak çalışmalarda R5 gelişme döneminde alınacak NDVI okumalarının önemli bir fikir verebileceği söylenebilir. Soyada SPAD ölçümleri, köklerde oluşan düzenli ve düzensiz oluşan nodulasyonun yoğunluğunun tahmin edilmesiyle ilgili yapılan çalışmalarda (Gwata ve ark. 2004), yapraklardaki fotosentetik aktivite ile klorofilmetre (SPAD) okumaları arasındaki ilişkinin saptanması çalışmalarında (Ma ve ark., 1995), nodul kuru ağırlığı ile yaprak klorofil içeriği arasındaki pozitif ilişkinin saptanması (Mirza ve ark., 1990; Sinclair ve ark., 1991) gibi çalışmalarda kullanılmıştır.
Diğer yandan SPAD ölçümleri diğer bitkilerde hasattan önce verimi tahmin etmede de kullanılmaktadır. Buğday da gelişmenin değişik evrelerinde, bayrak yapraktan, SPAD okuması yapılarak, yüksek doğrulukta verim tahmini Bavec ve Bavec, (2001) tarafından yapılmıştır. Bizim çalışmamızda ise, üç dönemde (V3, R2, R5) yapılan ölçümlerde SPAD değerlerinin tohum verimiyle olan ilişkisi incelendiğinde, her iki yılda da özellikle R2 (tam çiçeklenme) döneminde pozitif ve önemli korelasyon olduğu, tespit edilmiştir. 2015 yılında, tohum verimiyle V3, R2, R5 dönemlerinde ölçümü yapılan SPAD değerleri arasındaki korelasyon Şekil 1'de verilmiştir. 




Şekil 2. Soya hat ve çeşitlerin iki yıl birleşik olarak tohum verimi ve V3 (üç gerçek yapraklı dönem), R2 (tam çiçeklenme) ve R5 (tohum oluşum başlangıcı) büyüme dönemleri NDVI (normalize edilmiş fark bitki örtüsü indeksi) değerleri arasındaki korelasyon grafiği

Figure 2. Correlation graph between NDVI (normalized difference vegetation index) values of growth periods of $V 3$ (three real leaf period), R2 (full flowering) and $R 5$ (beginning of seed creation) for two years yield of soybean line and cultivars

Şekil 1 incelendiğinde R2 (tam çiçeklenme) döneminde pozitif $\left(r=0.40^{* *}\right)$ ve önemli $(p<0.01)$ korelasyon olduğu görülmektedir. Çizelge 4'ten 2015 yılında NDVI (Normalized Difference Vegetation Index) ölçümlerinin, ortalama değerlerinin, 0.565 ile 0.712 arasında, 2016 yılında ise 0.716 ile 0.822 arasında değiştiği görülebilmektedir. Yıllar arasındaki farklılığın, iklim koşullarından kaynaklanmış olduğu düşünülmektedir. Çizelge 4'ten kanopi sıcaklığı bakımından her üç dönemde (V3, R2, R5) yapılan ölçümlerin ortalamaları alınarak varyans analizine tabi tutularak, LSD testi ile gruplandırma yapılmıştır. 2015 yılında, kanopi sıcaklıkları $23.47{ }^{\circ} \mathrm{C}$ ile $26.54{ }^{\circ} \mathrm{C}$ arasında değiştiği, ortalamanın ise 24.89 ${ }^{\circ} \mathrm{C}$ olduğu görülebilmektedir. 2016 yılında ise araştırmaya konu olan genotiplerin kanopi sıcaklıkları arasında istatistiki anlamda fark görülmediğinden gruplandırma yapılmamıştır. Bitkilerde yaprak sıcaklıklarında görülen sıcaklık artışları, stomaların kapanmasına ve $\mathrm{CO}_{2}$ alımının engellenmesine, dolayısıyla fotosentetik aktivitenin engellenmesine neden olmaktadır (Vermeulen ve ark., 2007). Bu nedenle, yaprak sıcaklığı, bitki osmotik potansiyeli hakkında bilgi veren ve stomatal regülasyonu ile, su stresi belirleyicisi olarak kullanılabilen bir parametre olarak öne çıkmıştır (Ya ve ark., 2009). Stomalarını bu şekilde ayarlayarak sıcaklık stresine en iyi uyum sağlayabilen genotipler, dolayısıyla en iyi verim alınabilen genotipler olacaktır. 


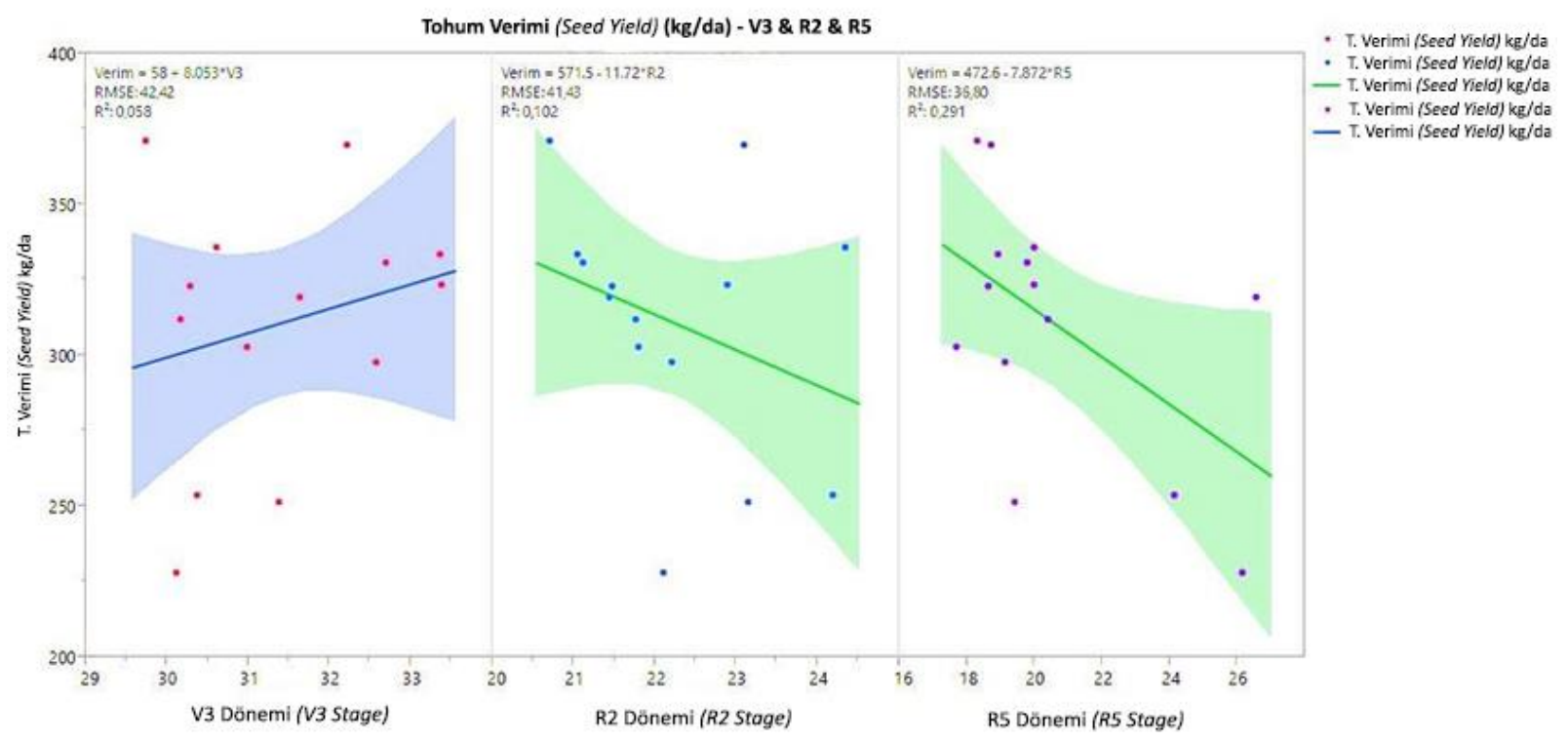

Şekil 3. Soya hat ve çeşitlerin tohum verimi ve V3 (üç gerçek yapraklı dönem), R2 (tam çiçeklenme) ve R5 (tohum oluşum başlangıcı) büyüme dönemleri kanopi sıcaklıkları $\left({ }^{\circ} \mathrm{C}\right.$ ) arasındaki korelasyon grafiği

Figure 3. Correlation graph between canopy temperatures $\left({ }^{\circ} \mathrm{C}\right.$ ), growth periods of V3 (three real leaf period), R2 (full flowering) and R5 (beginning of seed creation) and seed yield of soybean lines and cultivar

Şekil 3 incelendiğinde, V3 büyüme döneminde kanopi sıcaklığı ve tohum verimi arasında, $(r=24.17)$ pozitif ve istatistiksel olarak önemsiz ( $p>0.05), \mathrm{R} 2$ büyüme döneminde $(r=-31.89)$ negatif ve istatistiki olarak önemsiz( $p>0.05)$ ve R5 büyüme döneminde ( $r=-0.5399 *)$ ise negatif ve istatistiksel açıdan önemli $(p<0.05)$ bir korelasyon olduğu görülmektedir.

\section{Sonuçlar}

Harran Ovası koşullarında bazı soya hat ve çeşitlerinin tohum verimleriyle fizyolojik parametreler arasındaki ilişkinin saptanması amacıyla 2015 ve 2016 yıllarında yapılan çalışma sonucunda; 2015 yılına ölçülen SPAD değerleriyle tohum verimi arasında R2 (tam çiçeklenme) gelişme döneminde istatistiksel olarak önemli $(p<0.01)$ ve pozitif ( $r=0.40$ ) ilişki, R5 ( Tohum oluşumu başlangıcı) gelişme döneminde ise istatistiksel olarak önemsiz ( $p>0.05)$ olmakla birlikte ve negatif korelasyon olduğu saptanmıştır. NDVı ölçümlerinde ise R2 ve R5 dönemlerinde yapılan ölçümlerin soyada verim tahmini bakımından önem arz ettiği özellikle R5 döneminde yapılan ölçümlerin $\left(r=0.4960^{* *}\right)$ isabet oranının daha yüksek olacağı tespit edilmiştir. Kanopi sıcaklığında da R5 gelişme döneminde yapılan ölçümlerde tohum verimiyle negatif ( $r=-0.5399 * *$ ) korelasyon olduğu görülmüştür. Bu bulgular ışığında soyada yapılacak ıslah çalışmalarında erken 
jenerasyon hat seleksiyonunda R5

döneminde yapılacak SPAD, NDVI ve

kanopi sıcaklığı ölçümlerinin

kullanılabileceği sonucuna varılmıştır.

\section{Kaynaklar}

Acar, N., 2014. Değişik Kökenli Farklı Soya [Glycine max (L.) Merrill] Çeşitlerinin Kahramanmaraş Koşullarında Ana Ürün ve II. Ürün Olarak Verim ve Kalite Özelliklerinin Belirlenmesi. Kahramanmaraş Sütçü İmam Üniversitesi, Fen Bilimleri Enstitüsü, Yüksek Lisans Tezi, Kahramanmaraş, 92s.

Anonim, 2015. GAP Tarımsal Araştırma Enstitüsü Müdürlüğü Enstitü Yıllığı-2012, Yayın No:165, Şanlıurfa, s.41-42.

Anonim, 2016a. https:// goo.gl/Iqm5et. Erişim Tarihi:14.03.2016.

Anonim, 2016b. Şanlıurfa ìli İklim Verileri. Şanlıurfa Meteoroloji Bölge Müdürlüğü Kayıtları, Şanlıurfa.

Arıoğlu, H., Arslan, M., ve İşler, N., 1992. Çukurova Koşullarında II. Ürün Olarak Yetişen Bazı Soya Çeşitlerinin Önemli Tarımsal ve Bitkisel Özelliklerinin Belirlenmesi. Çukurova Üniversitesi Ziraat Fakültesi Dergisi 7(3):191-206.

Arıoğlu, H. H., 2000. Yağ Bitkileri Yetiştirme ve Islahı. Çukurova Üniversitesi, Ziraat Fakültesi, Tarla Bitkileri Bölümü Ders Kitabı, Çukurova Üniversitesi, Ziraat Fakültesi Ofset Atölyesi II. Baskı 40s.

Arslan, D., 2007. Soyada (Glycine max (L.) Merill), Ana ve İkinci Ürün Ekim Zamanlarında Yapılan Seleksiyonların Verim ve Verim Öğelerine Etkileri. On Dokuz Mayıs Üniversitesi, Fen Bilimleri Enstitüsü, Yüksek Lisans Tezi, Samsun, 52s.

Babar, M.A., Reynolds, M.P., Van Ginkel, M., Klatt, A.R., Raun, W.R., and Stone, M.L., 2006. Spectral Reflectance to Estimate Genetic Variation for In-Season Biomass, Leaf Chlorophyll, and Canopy Temperature in Wheat. Crop Sci., 46:1046-1057.

Bavec, F. and Bavec, M., 2001. Chlorophyll Meter Readings of Winter Wheat Cultivars and Grain Yield Prediction. Commun. Soil Sci. Plant Anal. Res., 32: 2709-2719.

Beyyavaş, V., Haliloğlu, H.,Yılmaz, A., 2007. İkinci Ürün Soya Tarımında Farklı Ekim
Zamanlarının Verim ve Verim Unsurlarına Etkisi. Harran Üniversitesi, Ziraat Fakültesi Dergisi, 11 37(4): 23-32.

Çekiç, C., 2007. Kurağa Dayanıklı Buğday (Triticum aestivum L.) Islahında Seleksiyon Kriteri Olabilecek Fizyolojik Parametrelerin Araştırılması. Ankara Üniversitesi, Fen Bilimleri Enstitüsü, Doktora Tezi, Ankara, $124 s$.

Çetin, S.H., 2010. Soyada Bakteri Aşılaması ve Fosfor Uygulamalarının Verim ve Kalite Üzerine Etkileri. Selçuk Üniversitesi, Fen Bilimleri Enstitüsü, Yüksek Lisans Tezi, Ankara, 58s.

Çopur, O., Gür, M. A., Demirel, U. ve Karakuş, M., 2009. Performance of Some Soybean [Glycine max (L.) Merrill] Genotypes Double Cropped in Semi-arid Conditions. Not. Bot. Hort. Agrobot., 37 (2): 85-91.

Dolapçı, F.,2012. Kahramanmaraş Koşullarında Bazı Soya [Glycine max. (L.) Merill] Çeşitlerinin Verim ve Verim Unsurlarının Belirlenmesi. Kahramanmaraş Sütçü İmam Üniversitesi, Fen Bilimleri Enstitüsü, Yüksek Lisans Tezi, Kahramanmaraş 45s.

Erbil, E., 2013. Şanlıurfa Koşullarında Kışlık ve Yazlık Bazı Şeker Pancarı Çeşitlerinin Verim ve Kalite Özelliklerinin Belirlenmesi. Harran Üniversitesi. Fen Bilimleri Enstitüsü, Yüksek Lisans Tezi, Şanlıurfa 60s.

Erdoğmuş, M., 2007. Soya Fasulyesi [Glycine Max (L.) Merrill.]' nde Erkenci Genotipler için Seleksiyonda Dikkate Alınacak Agronomik Özelliklerin Belirlenmesi. Ondokuz Mayıs Üniversitesi, Fen Bilimleri Enstitüsü, Yüksek Lisans Tezi, Samsun 45s.

FAO., 2014. http:// goo.gl/uBU1xD. Erişim Tarihi:14.09.2016

Ferencz, C., Bognar, P., Lichtenberger, J., Hamar, D., Tarscai, G and Timar, T., 2004. Crop Yield Estimation by Satellite Remote Sensing. International Journal of Remote Sensing, 25: 4113-4149.

Gutierrez, M., Norton, R., Thorp, K.R. and Wang, G.Y., 2012. Association of Spectral Reflectance Indices with Plant Growth and Lint Yield in Upland Cotton. Crop Sci., 52:849-857.

Güneş, A., 2006. İkinci Ürün Soya [Glycine max (L.) Merill] Tarımında Farklı Azot Doz ve Uygulama Zamanlarının Verim ve Verim Unsurlarına Etkisi. Harran Üniversitesi, Fen Bilimleri Enstitüsü, Yüksek Lisans Tezi, Şanlıurfa, 60s. 
Gwata, E.T., Wofford, D.S., Pfahler, P.L. and Boote, K.J., 2004. Genetics of Promiscuous Nodulation in Soybean: Nodule Dry Weight and Leaf Color Score. J. Hered., 95: 154-157.

Hede, A.R., Skovmand, B., Reynolds, M.P., Crossa, J., Vilhelmsen, A.L. and Stolen, O., 1999. Evaluating Genetic Diversity for Heat Tolerance Traits in Mexican Wheat Landraces. Genetic Resources and Crop Evolution, 46(1): 37-45.

Karakuş, M., Arslan, H., Hatipoğlu, H. ve Rastgeldi, U., 2011. Harran Ovası Koşullarına Uygun Ana ve İkinci Ürün Bazı Soya Hat ve Çeşitlerinin Belirlenmesi. Türkiye IX. Tarla Bitkileri Kongresi, 12-15 Eylül 2011, Bursa, Cilt II: 1064-1067.

Kastens, J.H., Kastens, T.L., Kastens, D.L.A., Price, K.P., Martinko E.A. and Le, R.Y., 2005. Image Masking for Crop Yield Forecasting Using AVHRR NDVI Time Series Imagery. Remote Sensing of Environment, 99: 341356.

Khan, S., Latif, A., Ahmad, S.Q., Ahmad, F. and Fida, M., 2011. Genetic Variability Analysis in Some Advanced Lines of Soybean [Glycine max (L.) Merrill] Asian Journal of Agricultural Sciences 3(2): 138-141.

Kınacı, M., 2011. Çanakkale Koşullarında Soya Fasulyesi Çeşitlerinin Verim ve Bazı Kalite Unsurlarının Belirlenmesi. Selçuk Üniversitesi, Fen Bilimleri Enstitüsü, Yüksek Lisans Tezi, Konya, 69s.

Ma, B.L., Morrison, M.J., Voldeng, H.D., 1995. Leaf Greenness and Photosynthetic Rates of Soybean. Crop Sci., 35: 1411-1414.

Malik, M.F.A., Ashraf, M., Qureshi, A.S. and Khan, M.R., 2011. Investigation and Comparison of Some Morphological Traits of the Soybean Populations Using Cluster Analysis. Pak. J. Bot., 43(2): 1249-1255.

Manjunath, K.R., Potdar, M.B., Purohit, N.L. 2002. Large Area Operational Wheat Yield Model Development and Validation Based on Spectral and Meteorological Data. International Journal of Remote Sensing 23: 3023-3038.

Matsunaka, T., Watanabe, Y., Miyawaki, T., Ichikawa, N., 1997. Prediction of Grain Protein Content in Winter Wheat Through Leaf Colour Measurements Using a Chlorophyll Meter. Soil Sci. Plant Nutr. 43, 127-134.

Mirza, N.A, Bohlool B.B. and Somasegeran P., 1990. Nondestructive Chlorophyll Assay for Screening of Strains of Bradyrhizobium japonicum. Soil Biol Biochem ,22: 203-207.

Mkhabela, M.S., Bullock, P., Raj, S., Wang, S. and Yang, Y. 2011. Crop Yield Forecasting on the Canadian Prairies Using MODIS NDVI Data. Agricultural and Forest Meteorology 151: 385-393.

Plant, R.E., Munk, D.S., Roberts, B.R., Vargas, R.N., Travis, R.L., Rains, D.W., Hutmacher, R.B., 2001. Application of Remote Sensing to Strategic Questions in Cotton Management and Research. J Cotton Sci. (5):30-41.

Poehlman, J.M., 1979. Breeding Field Crops, 2nd edition, The Avi Publishing Company, Inc., Connecticut, 483s.

Prasad, A.K., Chai, L., Singh, R.P., Kafatos, M., 2006. Crop Yield Estimation Model for lowa Using Remote Sensing and Surface Parameters. International Journal of Applied Earth Observation and Geoinformation (8): 26-33.

Reeves, D.W., Mask, P.L., Wood, C.W., Delaney, D.P., 1993. Determination of Wheat Nitrogen Status with a Hand-held Chlorophyll Meter: Influence of Management Practices. J. Plant Nutr. 16 (5):781-796.

Reynolds, M.P., Singh, R.P., Ibrahim, A., Ageeb, O.A.A., Larque-Saavedra, A. and Quick, J.S., 1998. Evaluating Physiological Traits to Complement Empirical Selection for Wheat in Warm Environments. Euphytica. Research, 100: 85-94.

Rharrabti, Y., Villegas, D., Garcia Del Moral, D.F., Aparicio, N., Elhani, S. and Royo, C., 2001. Environmental and Genetic Determination of Protein Content and Grain Yield in Durum Wheat Under Mediterranean Conditions. Plant Breeding Research, (120): 381-388.

Royo, C., Villegas, D., Garcia Del Moral, L.F., Elhani, S., Aparacio, N., Rharrabti, Y. and Araus, J.L., 2002. Comparative Performance of Carbon Isotope Discrimination and Canopy Temperature Depression as Predictors of Genotype Differences in Durum Wheat Yield in Spain. Australian Journal of Agricultural Research, 53: 561-569.

Sarımehmetoğlu, O., 2006. Çukurova Bölgesi Çiftçi Koşullarında Yetiştirilen Soya Ürününde Bazı Önemli Kalite Özelliklerinin Belirlenmesi. Çukurova Üniversitesi, Fen 
Bilimleri Enstitüsü, Yüksek Lisans Tezi, Adana, 74s.

Sinclair, T.R., Soffes. A.R., Hinson. K., Albrcecht, S.L. and Pfahler, P.L., 1991. Genotypic Variation in Soybean Nodule Number and Weight. Crop Sci., (31):301-304.

Sinclair, T.R. and Vadez, V., 2012. The Future of Grain Legumes in Cropping Systems. Crop Pasture Sci. (63):501-512.

Söğüt, T., 2005. Aşılama ve Azotlu Gübre Uygulamasının Bazı Soya Çeşitlerinin Verim ve Verim Özelliklerine Etkisi. Akdeniz Üniversitesi, Ziraat Fakültesi Dergisi, 18(2):213-218.

Ünal, ì., 2007. Melezleme Yöntemiyle Elde Edilen Soya [Glycine $\max$ (L.) Merr.] Hatlarının Bazı Tarımsal Özelliklerinin Belirlenmesi. Selçuk Üniversitesi, Fen Bilimleri Enstitüsü, Yüksek Lisans Tezi, Konya, 54s.

Van Roekel, R.J., Purcell, L.C., 2014. Soybean Biomass and Nitrogen Accumulation Rates and Radiation Use Efficiency in a Maximum Yield Environment. Crop Sci., 54: 1189-1196.

Vermeulen, K., Steppe, K., Liunh, N.S., Lemeur, R., De Backer, L., Bleyaert, P., Dekock, J., Aerts, J.M., Berckmans, D., 2007. Simultaneous Response of Stem Diameter, Sap Flow Rate and Leaf Temperature of Tomato Plants to Drought Stress. ActaHort., 801:1259-1266.
Wang, RC., Huang, JF., 2002. Rice Yield Estimation Using Remote Sensing data. Beijing: China Agriculture Press. 287 p. (in Chinese with English abstract).

Ya, L., JunQiang, D., Chander, S., DengQun, L., JiuRan, Z., JianSheng, L., 2009. Identification of Maize Drought-Tolerance at Seedling Stage Based on Leaf Temperature Using Infrared Thermography. Scientia Agricultura Sinica, 42(6):2192-2201.

Yıldırım, M., 2005. Seçilmiş Altı Ekmeklik Buğday (Triticum aestivum L.) Diallel F1 Melez Döllerinde Bazı Tarımsal ve Fizyolojik Kalite Karakterlerinin Kalıtımı Üzerinde Bir Araştırma. Çukurova Üniversitesi, Fen Bilimleri Enstitüsü, Doktora Tezi, Adana, 314s.

Yılmaz, A., Beyyavaş, V., Cevheri, İ. ve Haliloğlu, H., 2005. Harran Ovası Ekolojisinde İkinci Ürün Olarak Yetiştirilebilecek Bazı Soya [Glycine max. (L.) Merrill.] Çeşit ve Genotiplerinin Belirlenmesi. Harran Üniversitesi, Ziraat Fakültesi Dergisi, 9(2):55-61.

Zhang, L., Wang, R. and J. D. Hesketh., 2001. Effects of Photoperiod on Growth and Development of Soybean Floral Bud in Different Maturity. Agronomy Journal 93: 944-948. 